\title{
Original Article \\ Maternal Baicalin Treatment Increases Fetal Lung Surfactant Phospholipids in Rats
}

\author{
Chung-Ming Chen, ${ }^{1,2}$ Leng-Fang Wang, ${ }^{3}$ and Kur-Ta Cheng ${ }^{3}$ \\ ${ }^{1}$ Department of Pediatrics, Taipei Medical University Hospital, Taipei, Taiwan \\ ${ }^{2}$ Department of Pediatrics, School of Medicine, College of Medicine, Taipei Medical University, Taipei, Taiwan \\ ${ }^{3}$ Department of Biochemistry, School of Medicine, College of Medicine, Taipei Medical University, Taipei, Taiwan
}

Correspondence should be addressed to Chung-Ming Chen, cmchen@tmu.edu.tw

Received 30 December 2008; Accepted 26 May 2009

Copyright (C) 2011 Chung-Ming Chen et al. This is an open access article distributed under the Creative Commons Attribution License, which permits unrestricted use, distribution, and reproduction in any medium, provided the original work is properly cited.

\begin{abstract}
Baicalin is a flavonoid compound purified from the medicinal plant Scutellaria baicalensis Georgi and has been reported to stimulate surfactant protein (SP)-A gene expression in human lung epithelial cell lines (H441). The aims of this study were to determine whether maternal baicalin treatment could increase lung surfactant production and induce lung maturation in fetal rats. This study was performed with timed pregnant Sprague-Dawley rats. One-day baicalin group mothers were injected intraperitoneally with baicalin $(5 \mathrm{mg} / \mathrm{kg} /$ day) on Day 18 of gestation. Two-day baicalin group mothers were injected intraperitoneally with baicalin $(5 \mathrm{mg} / \mathrm{kg} / \mathrm{day})$ on Days 17 and 18 of gestation. Control group mothers were injected with vehicle alone on Day 18 of gestation. On Day 19 of gestation, fetuses were delivered by cesarean section. Maternal treatment with 2-day baicalin significantly increased saturated phospholipid when compared with control group and total phospholipid in fetal lung tissue when compared with control and 1-day baicalin groups. Antenatal treatment with 2-day baicalin significantly increased maternal growth hormone when compared with control group. Fetal lung SP-A mRNA expression and maternal serum corticosterone levels were comparable among the three experimental groups. Maternal baicalin treatment increases pulmonary surfactant phospholipids of fetal rat lungs and the improvement was associated with increased maternal serum growth hormone. These results suggest that antenatal baicalin treatment might accelerate fetal rat lung maturation.
\end{abstract}

\section{Introduction}

Respiratory distress syndrome (RDS) is a major cause of morbidity and mortality in preterm neonates. Maternal glucocorticoid treatments given to women at high risk of preterm delivery have been used extensively to decrease the incidence and severity of RDS [1]. It was suggested that the beneficial effect of glucocorticoid did not occur if there was an interval of over 7 days between treatment and delivery [2]. These findings persuaded obstetricians to repeat the course of glucocorticoid after 7 days in pregnant women at risk of preterm delivery who had not yet given birth. However, there is considerable evidence from laboratory and clinical studies that repeated antenatal steroid administration is associated with decreased birth body weight, length and head circumference and no additional benefits in pretermbirth outcomes $[3,4]$. These studies indicate that maternal glucocorticoid could not completely prevent the incidence of
RDS and have untoward neurological side effects after multiple doses and that there are other potent lung maturation factors that remain to be identified.

The extract from the root of Scutellaria baicalensis Georgi (Scutellaria Radix) is the main component in Chinese medicine prescribed for miscarriage, threatened abortion, and neonatal hyperbilirubinemia. It is composed of four major flavenoids, that is, baicalin, baicalein, wogonin and wogonoside. Baicalin (Figure 1), 5,6,7-trihydroxyflavone-7- $\beta$-D-glucuronide, has antibacterial, antiviral, anti-inflammatory, anti-oxidative and anticancer activities [5-8]. It has been used as an antiinflammatory and protective agents in the treatment of experimental pancreatitis and liver injury $[9,10]$. We found that baicalin stimulates surfactant protein (SP)A gene expression through induction of cytochrome $\mathrm{c}$ oxidase in human lung epithelial cell lines (H441) [11]. We hypothesized that maternal baicalin treatment might 
increase fetal lung surfactant production in vivo in preterm rats and quantified the effects by biochemical and molecular analyses.

\section{Methods}

2.1. Animals and Experimental Procedures. The Animal Care and Use Committee at Taipei Medical University approved this study. This study was performed with timed pregnant Sprague-Dawley rats (vaginal smear positive, Day 0; term, Day 22). One-day baicalin group mothers $(n=2)$ were injected intraperitoneally (i.p.) with baicalin $(5 \mathrm{mg} / \mathrm{kg} / \mathrm{day}$, Wako Pure Chemical Industries, Japan) on Day 18 of gestation. Two-day baicalin group mothers $(n=3)$ were injected i.p. with baicalin $(5 \mathrm{mg} / \mathrm{kg} /$ day $)$ on Days 17 and 18 of gestation. Baicalin was dissolved in dimethyl sulfoxide (DMSO) at a concentration of $5 \mathrm{mg} / \mathrm{ml}$. The dose of baicalin was based on the work of P.-L. Tsai and T.-H. Tsai [12]. Control group mothers $(n=3)$ were similarly injected with DMSO alone on Day 18 of gestation. On Day 19 of gestation, all dams were anesthetized with pentobarbital $(50 \mathrm{mg} / \mathrm{kg}$, i.p., Abbott Laboratories, North Chicago, IL, USA), and cesarean section was used to deliver the fetuses. At delivery, the fetuses were weighed and killed by an i.p. injection of pentobarbital $(100 \mathrm{mg} / \mathrm{kg})$. The organs of interest were then dissected free and weighed to the nearest $0.1 \mathrm{mg}$. Results were expressed as organ weight and the ratio (\%) of organ/body weight. After delivery of the fetuses, a blood sample was taken from the pregnant mother before she was sacrificed. Plasma was immediately separated from blood cells by centrifugation and kept at $-20^{\circ} \mathrm{C}$ for hormone measurements.

2.2. Biochemical Analysis. Lungs were homogenized and aliquots were extracted with chloroform-methanol [13]. Lipid extracts from aliquots of the lung homogenates were treated with osmium tetroxide, and saturated phospholipid was recovered by alumina column chromatography and quantified using a phosphorus assay $[14,15]$. Values were expressed as $-\mathrm{mol} / \mathrm{g}$ protein. Aliquots of the lung homogenate from each animal were used to measure the total protein content by Bio-Rad protein assay kit using bovine serum albumin as a standard.

Maternal serum growth hormone concentrations were measured using a commercially available radioimmunoassay kit (Diagnostic Systems Laboratories, Webster, TX, USA). Maternal serum corticosterone levels were measured using an enzyme immunoassay kit (BIOCODE, Liège, Belgium).

2.3. Molecular Analysis. Gene expression of SP-A was measured with reverse transcriptase-polymerase chain reaction (RT-PCR). Total RNA was isolated from lung using the guanidine isothiocyanate based TRIzol solution (Invitrogen Life Technologies, Paisley, UK) according to the manufacturer's specifications and quantified by measurement of absorbance at $260 \mathrm{~nm}$. Total RNA ( $\left.2^{-\mathrm{g}}\right)$ was converted to first strand cDNA with oligo(dT) primer and reverse transcriptase. The primer sequences used in PCR for SP-A cDNA are 5'-GGAAGCCCTGGGATCCCTGGA-3'

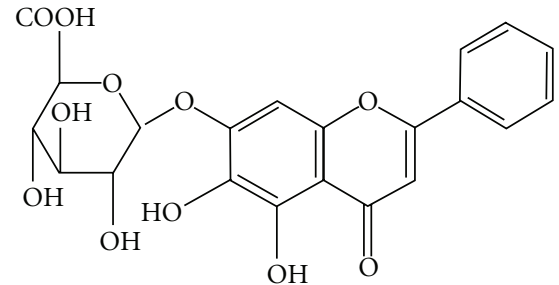

FIgURE 1: Chemical structure of baicalin.

TABle 1: Maternal treatment effects on fetal body weight and lung/body weight ratio.

\begin{tabular}{lcccc}
\hline Treatment & $n$ & $\begin{array}{c}\text { Body weight } \\
(\mathrm{g})\end{array}$ & $\begin{array}{c}\text { Lung weight } \\
(\mathrm{g})\end{array}$ & $\begin{array}{c}\text { Lung/body } \\
\text { weight }(\%)\end{array}$ \\
\hline $\begin{array}{l}\text { Control } \\
\text { Baicalin }\end{array}$ & 27 & $2.48 \pm 0.07$ & $0.098 \pm 0.004$ & $3.90 \pm 0.09$ \\
$\begin{array}{l}1 \text { day }) \\
\begin{array}{l}\text { Baicalin } \\
(2 \text { days })\end{array}\end{array}$ & 21 & $2.62 \pm 0.05$ & $0.094 \pm 0.002$ & $3.63 \pm 0.08$ \\
\hline
\end{tabular}

Values are mean \pm SEM. $n$ is the number of fetuses tested.

and $5^{\prime}$-AGGCTTTGTCCCCACAG- $3^{\prime}$ with an expected size of 558 base pairs (accession no. M33201). $\beta$-Actin (BD Biosciences Clontech, Palo Alto, CA, USA) was used as an internal control. The PCR reactions were carried out using the following conditions: $94^{\circ} \mathrm{C}$ for 1 min followed by $60^{\circ} \mathrm{C}$ for $1 \mathrm{~min}$ and $72^{\circ} \mathrm{C}$ for $1 \mathrm{~min}$. The primer annealing temperature was $60^{\circ} \mathrm{C}$ with 29 cycles for SP-A and 33 cycles for $\beta$-actin. SP-A mRNA expressions were determined by running the samples at the optimal cycle number, which was selected in the region of linearity between cycle number and PCR product intensity. Products were visualized on ethidium bromide-stained gels and quantified using the BioRad Gel Documentation System (BioRad Laboratories, Hercules, CA, USA).

2.4. Statistical Analysis. Results are presented as the mean \pm SEM. Statistically significant differences were analyzed by ANOVA followed by Bonferroni post hoc analysis. Differences were considered significant at $P<.05$.

\section{Results}

There were 27 fetuses from three rats in the control group, 21 fetuses from two rats in the 1-day baicalin group and 22 fetuses from three rats in the 2-day baicalin group. There was no significant difference in litter size among the three experimental groups.

3.1. Maternal Baicalin Treatment Effects on Fetal Body Weight, Organ Weight and Organ/Body Weight Ratio (\%). Effects of maternal baicalin treatment on fetal body weight and the organ/body weight ratio (\%) are presented in Tables 1 and 2. The body weight, lung, brain and kidney weights, and lung/body weight, brain/body weight and kidney/body weight ratios were comparable among the three experimental 
TABLE 2: Maternal treatment effects on organ weight and organ/body weight ratio.

\begin{tabular}{lccccccc}
\hline Treatment & $n$ & $\begin{array}{c}\text { Brain weight } \\
(\mathrm{g})\end{array}$ & $\begin{array}{c}\text { Brain/body } \\
\text { weight }(\%)\end{array}$ & $\begin{array}{c}\text { Kidney weight } \\
(\mathrm{g})\end{array}$ & $\begin{array}{c}\text { Kidney/body } \\
\text { weight }(\%)\end{array}$ & $\begin{array}{c}\text { Liver weight } \\
(\mathrm{g})\end{array}$ & $\begin{array}{c}\text { Liver/body } \\
\text { weight }(\%)\end{array}$ \\
\hline Control & 27 & $0.109 \pm 0.003$ & $4.47 \pm 0.12$ & $0.020 \pm 0.001$ & $0.81 \pm 0.02$ & $0.22 \pm 0.01$ & $8.67 \pm 0.21$ \\
Baicalin (1 day) & 21 & $0.113 \pm 0.002$ & $4.37 \pm 0.08$ & $0.020 \pm 0.000$ & $0.79 \pm 0.02$ & $0.23 \pm 0.00$ & $8.97 \pm 0.17$ \\
Baicalin (2 days) & 22 & $0.113 \pm 0.04$ & $4.32 \pm 0.15$ & $0.021 \pm 0.001$ & $0.81 \pm 0.02$ & $0.25 \pm 0.01^{*}$ & $9.54 \pm 1.01^{* *}$ \\
\hline
\end{tabular}

Values are mean \pm SEM. $n$ is the number of fetuses tested. ${ }^{*} P<.05,{ }^{*} P<.01$ compared with the control group.

TABLE 3: Maternal treatment effects on saturated phosphatidylcholine and total phospholipids in fetal lung tissue of preterm rats.

\begin{tabular}{lcll}
\hline Treatment & $n$ & $\begin{array}{l}\text { Saturated phospholipid } \\
(\mu \text { mol/g protein })\end{array}$ & $\begin{array}{l}\text { Total phospholipid } \\
(\mu \mathrm{mol} / g \text { protein })\end{array}$ \\
\hline $\begin{array}{l}\text { Control } \\
\text { Baicalin } \\
(1 \text { day })\end{array}$ & 9 & $31.02 \pm 0.98$ & $199.21 \pm 9.57$ \\
$\begin{array}{l}\text { Baicalin } \\
(2 \text { days })\end{array}$ & 13 & $39.35 \pm 1.97^{\#}$ & $216.24 \pm 4.67$ \\
\hline
\end{tabular}

Values are mean \pm SEM. $n$ is the number of fetuses tested. ${ }^{* *} P<.01$ compared with the control and 1-day baicalin groups, ${ }^{\#} P<.01$ compared with the control group.

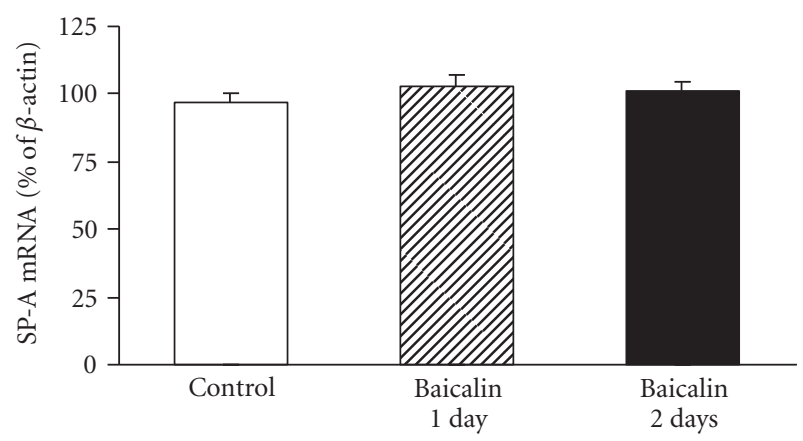

FIGURE 2: Maternal baicalin treatment effects on SP-A mRNA expression of fetal lung tissue in the control $(n=23), 1$-day baicalin $(n=19)$ - and 2-day baicalin $(n=15)$-treated preterm rats. Data are expressed as the mean \pm SEM.

groups. Two-day baicalin-treated fetuses had significantly higher liver weight and liver/body weight ratio than did the control group.

3.2. Fetal Lung Phospholipid. Maternal treatment with baicalin increased saturated phospholipid in fetal lung tissue, and the value reached statistical significance in the 2-day baicalin-treated group when compared with control animals (Table 3). Two-day baicalin-treated fetuses had significantly higher total phospholipid than did the control and 1-day baicalin-treated groups.

3.3. Fetal Lung SP-A mRNA Expression. The SP-A mRNA expression in fetal lung tissue was comparable among the three experimental groups (Figure 2).

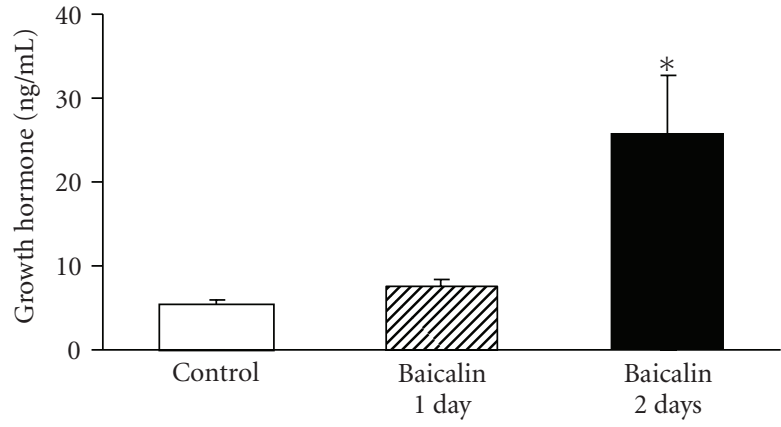

(a)

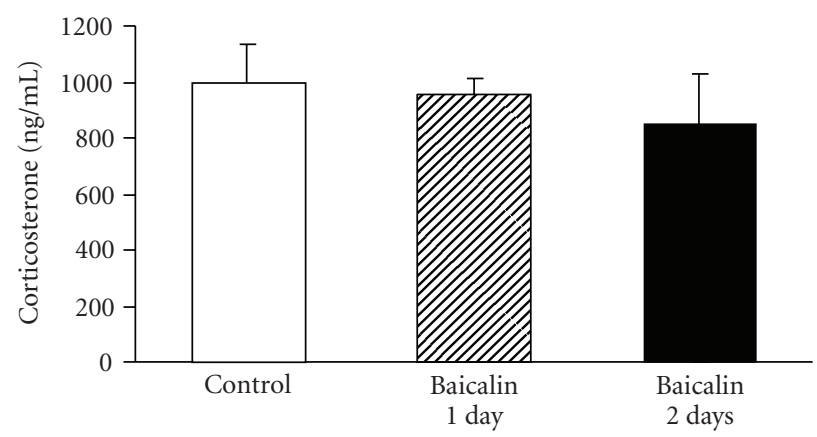

(b)

FIGURE 3: (a) Growth hormone and (b) corticosterone serum levels in the control $(n=3), 1$-day baicalin $(n=2)$ - and 2-day baicalin $(n=3)$-treated dams. Data are expressed as the mean \pm SEM. $* P<$ .05 compared with the control group.

3.4. Growth Hormone and Corticosterone Levels in Maternal Serum at Delivery. Antenatal treatment with 2-day baicalin significantly increased maternal growth hormone when compared with control group (Figure 3(a)). Corticosterone concentrations in maternal serum were comparable among the three experimental groups (Figure 3(b)).

\section{Discussion}

Neonatal respiratory failure is a serious clinical problem associated with high morbidity, mortality and costs [16, 17]. The major risk factor is premature birth and its associated RDS. The pathophysiology of RDS is an immature lung structure and a deficit of pulmonary surfactant. Glucocorticoids have been reported to enhance fetal lung maturation and surfactant production [18]. However, there is considerable evidence that glucocorticoids have an adverse 
effect on the growth and development of the immature brain $[3,4]$. Baicalin has been reported to stimulate SP-A gene expression in vitro after $48 \mathrm{~h}$ of incubation [11]. Therefore, we investigated the effects of antenatal baicalin treatment $48 \mathrm{~h}$ before birth in preterm rats that have been shown to be a suitable model for the study of acute neonatal lung disease [19].

In this study, we found that antenatal baicalin treatment did not influence fetal body, brain, lung and kidney weight and 2-day baicalin treatment significantly increased liver weight and liver/body weight ratio as compared with that of the control group. It appears that baicalin promotes liver growth in this premature animal model. The increase in liver weight in the offspring of baicalin-treated dams is of interest, as others have reported that baicalin could prevent experimental hepatic fibrosis [20], although, to our knowledge, no increase in liver weight has been recorded.

Pulmonary surfactant stabilizes the lung by producing a surface-active monolayer that reduces the surface tension at the air-liquid interface of the terminal airways. This reduction in surface tension contributes to mechanical stability by preventing alveolar and bronchiolar collapse during expiration. Surfactant is composed of $\sim 90 \%$ lipids and $10 \%$ proteins. The surface activity property is due primarily to dipalmitoylphosphatidylcholine, which is $\sim 50 \%$ of surfactant by weight. Therefore, we measured the saturated phospholipid content in fetal lung tissue in this premature animal model. Four lung-specific proteins (SP-A, SP-B, SP$\mathrm{C}$ and SP-D) have been found to be associated with the surfactant [21]. Surfactant proteins are required both for the transition between lamellar bodies and tubular myelin, and for the spreading of tubular myelin components to the surface film. SP-A, the major pulmonary surfactantassociated protein, is a developmentally and hormonally regulated sialoglycoprotein of about 35000 mol wt. constituting about $50 \%$ of the total surfactant protein [22]. In addition to its direct effects on film adsorption and stability, SP-A seems to enhance the resistance of surfactant to protein inhibition and stimulates phagocytosis of bacteria and viruses by alveolar macrophages [23]. In this study, we found that antenatal baicalin treatment increased total phospholipids and saturated phospholipid levels, and did not affect SP-A mRNA expression in fetal lung tissue. This result is in contrast to our previous report of increased SP-A gene expression after incubation of H441 cells in the presence of baicalin [11]. These differences may suggest that a higher level of baicalin stimulation is required to enhance in vivo surfactant protein gene expression or cell-cell and matrixcell interactions might be implicated in the modulation of baicalin effects in lung development.

In this study, we found that 2-day baicalin treatment significantly increased maternal growth hormone levels. Growth hormone appears to have important effects on fetal metabolism and development. Lung is established as a target site for pituitary growth hormone action as pathophysiological states of pituitary growth hormone excess and deficiency are associated with impaired pulmonary function $[24,25]$. Growth hormone may be involved in lung

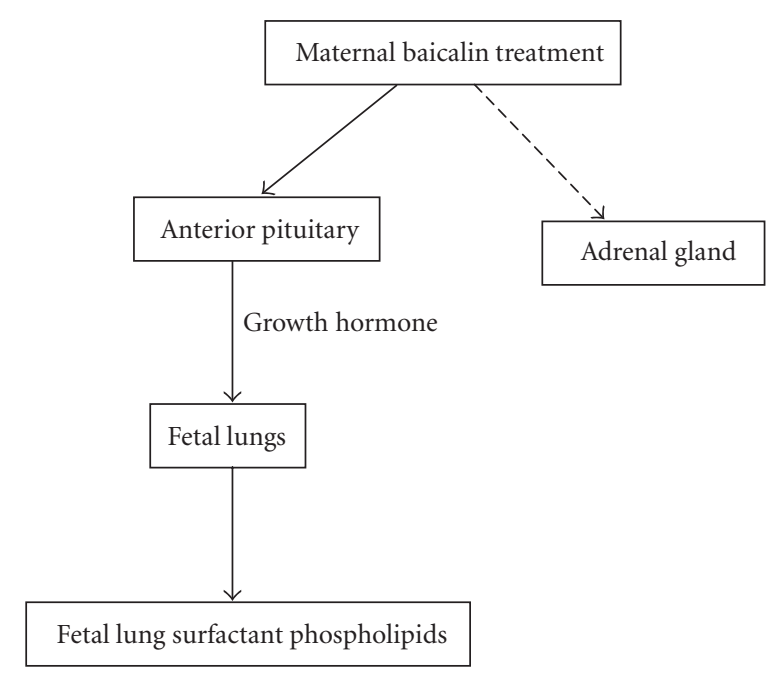

Figure 4: A hypothetical scheme of maternal baicalin treatment increases fetal rat lung surfactant phospholipids. Solid arrow indicates stimulation and dashed arrow indicates no effect.

development because it is present in extra-pituitary tissues of rat embryos [26]. The growth hormone receptor gene is also expressed in pulmonary tissues $[27,28]$. Therefore, pituitary growth hormone is possible to be an endocrine regulator of lung growth. These results suggest that baicalin has some hormonal effects. However, maternal corticosterone levels were comparable in the control and baicalin-treated groups. This result indicates that baicalin has no inhibitory effect on hypothalamic-pituitary-adrenal axis and the lung maturational effects of baicalin occurred independently of corticosterone [29].

In conclusion, maternal baicalin treatment at a dose of $5 \mathrm{mg} / \mathrm{kg} /$ day on Days 17 and 18 of gestation increases fetal rat lung surfactant phospholipids and the improvement was associated with increased maternal serum growth hormone. Figure 4 is a hypothetical scheme of maternal baicalin treatment increases fetal rat lung surfactant phospholipids. These results suggest that antenatal baicalin treatment might accelerate fetal rat lung maturation.

\section{Funding}

National Science Council (NSC90-2314-B-038-011).

\section{References}

[1] P. L. Ballard, "Hormonal regulation of pulmonary surfactant," Endocrine Reviews, vol. 10, no. 2, pp. 165-181, 1989.

[2] H. R. Gamsu, B. M. Mullinger, P. Donnai, and C. H. Dash, "Antenatal administration of betamethasone to prevent respiratory distress syndrome in preterm infants: report of a UK multicentre trial," British Journal of Obstetrics and Gynaecology, vol. 96, no. 4, pp. 401-410, 1989.

[3] N. P. French, R. Hagan, S. F. Evans, M. Godfrey, and J. P. Newnham, "Repeated antenatal corticosteroids: size at birth and subsequent development," American Journal of Obstetrics and Gynecology, vol. 180, pp. 114-121, 1999. 
[4] K. E. Murphy, M. E. Hannah, A. R. Willan et al., "Multiple courses of antenatal corticosteroids for preterm birth (MACS): a randomised controlled trial," The Lancet, vol. 372, no. 9656, pp. 2143-2151, 2008.

[5] I. X. Liu, D. G. Durham, and R. M. Richards, "Baicalin synergy with beta-lactam antibiotics against methicillin-resistant Staphylococcus aureus and other beta-lactam-resistant strains of S. aureus," Journal of Pharmacy and Pharmacology, vol. 52, pp. 361-366, 2000.

[6] Z. Gao, K. Huang, X. Yang, and H. Xu, "Free radical scavenging and antioxidant activities of flavonoids extracted from the radix of Scutellaria baicalensis Georgi," Biochimica et Biophysica Acta, vol. 1472, no. 3, pp. 643-650, 1999.

[7] C.-P. Chung, J.-B. Park, and K.-H. Bae, "Pharmacological effects of methanolic extract from the root of Scutellaria baicalensis and its flavonoids on human gingival fibroblast," Planta Medica, vol. 61, no. 2, pp. 150-153, 1995.

[8] L. S. Adams, N. P. Seeram, M. L. Hardy, C. Carpenter, and D. Heber, "Analysis of the interactions of botanical extract combinations against the viability of prostate cancer cell lines," Evidence-Based Complementary and Alternative Medicine, vol. 3, no. 1, pp. 117-124, 2006.

[9] D. Xue, W. Zhang, Y. Zhang, H. Wang, B. Zheng, and X. Shi, "Adjusting effects of baicalin for nuclear factor- $\kappa \mathrm{B}$ and tumor necrosis factor- $\alpha$ on rats with caerulein-induced acute pancreatitis," Mediators of Inflammation, vol. 2006, Article ID 26295, pp. 1-6, 2006.

[10] L.-L. Liu, L.-K. Gong, H. Wang et al., "Baicalin protects mouse from Concanavalin A-induced liver injury through inhibition of cytokine production and hepatocyte apoptosis," Liver International, vol. 27, no. 4, pp. 582-591, 2007.

[11] K.-T. Cheng, Y.-C. Huang, Y.-S. Lin, B. Su, and C.-M. Chen, "Effects of baicalin on the gene expression of surfactant protein A (SP-A) in lung adenocarcinoma cell line H441," Planta Medica, vol. 69, no. 4, pp. 300-304, 2003.

[12] P.-L. Tsai and T.-H. Tsai, "Pharmacokinetics of baicalin in rats and its interactions with cyclosporin A, quinidine and SKF525A: a microdialysis study," Planta Medica, vol. 70, no. 11, pp. 1069-1074, 2004.

[13] E. G. Bligh and W. J. Dyer, "A rapid method of total lipid extraction and purification," Canadian Journal of Physiology and Pharmacology, vol. 37, pp. 911-917, 1959.

[14] G. R. Barlett, "Phosphorous assay in column chromatography," Journal of Biological Chemistry, vol. 234, pp. 466-468, 1959.

[15] R. J. Mason, J. Nellenbogen, and J. A. Clements, "Isolation of disaturated phosphatidylcholine with osmium tetroxide," Journal of Lipid Research, vol. 17, no. 3, pp. 281-284, 1976.

[16] M. C. Walsh-Sukys, R. E. Bauer, D. J. Cornell, H. G. Friedman, E. K. Stork, and M. Hack, "Severe respiratory failure in neonates: mortality and morbidity rates and neurodevelopmental outcomes," Journal of Pediatrics, vol. 125, no. 1, pp. 104-110, 1994.

[17] D. C. Angus, W. T. Linde-Zwirble, G. Clermont, M. F. Griffin, and R. H. Clark, "Epidemiology of neonatal respiratory failure in the United States: projections from California and New York," American Journal of Respiratory and Critical Care Medicine, vol. 164, no. 7, pp. 1154-1160, 2001.

[18] P. M. Farrell and M. E. Avery, "Hyaline membrane disease," American Review of Respiratory Disease, vol. 111, no. 5, pp. 657-688, 1975.
[19] A. K. Tanswell, L. Wong, F. Possmayer, and B. A. Freeman, "The preterm rat: a model for studies of acute and chronic neonatal lung disease," Pediatric Research, vol. 25, no. 5, pp. 525-529, 1989.

[20] I. Shimizu, "Sho-saiko-to: Japanese herbal medicine for protection against hepatic fibrosis and carcinoma," Journal of Gastroenterology and Hepatology, vol. 15, pp. D84-D90, 2000.

[21] S. Hawgood and K. Shiffer, "Structures and properties of the surfactant-associated proteins," Annual Review of Physiology, vol. 53, pp. 375-394, 1991.

[22] S. Hawgood, B. J. Benson, and R. L. Halmilton Jr., "Effects of a surfactant-associated protein and calcium ions on the structure and surface activity of lung surfactant lipids," Biochemistry, vol. 24, pp. 184-190, 1985.

[23] F. van Iwaarden, B. Welmers, J. Verhoef, H. P. Haagsman, and L. M. van Golde, "Pulmonary surfactant protein A enhances the host-defense mechanism of rat alveolar macrophages," American Journal of Respiratory Cell and Molecular Biology, vol. 2, no. 1, pp. 91-98, 1990.

[24] D. Bartlett Jr., "Postnatal growth of the mammalian lung: influence of excess growth hormone," Respiration Physiology, vol. 12, no. 3, pp. 297-304, 1971.

[25] B. Merola, S. Longobardi, M. Sofia, R. Pivonello, A. Micco, F. di Rella et al., "Lung volumes and respiratory muscle strength in adult patients with childhood- or adult-onset growth hormone deficiency: effect of 12 months' growth hormone replacement therapy," European Journal of Endocrinology, vol. 135, pp. 553-558, 1996.

[26] J. A. Beyea, D. M. Olson, and S. Harvey, "Growth hormone expression in the perinatal and postnatal rat lung," Developmental Dynamics, vol. 232, no. 4, pp. 1037-1046, 2005.

[27] J. Garcia-Aragon, P. E. Lobie, G. E. O. Muscat, K. S. Gobius, G. Norstedt, and M. J. Waters, "Prenatal expression of the growth hormone $(\mathrm{GH})$ receptor/binding protein in the rat: a role for $\mathrm{GH}$ in embryonic and fetal development?" Development, vol. 114, no. 4, pp. 869-876, 1992.

[28] D. C. Batchelor, R. M. Lewis, B. H. Breier, P. D. Gluckman, and S. J. M. Skinner, "Fetal rat lung epithelium has a functional growth hormone receptor coupled to tyrosine kinase activity and insulin-like growth factor binding protein-2 production," Journal of Molecular Endocrinology, vol. 21, no. 1, pp. 73-84, 1998.

[29] F. Gómez, E. R. De Kloet, and A. Armario, "Glucocorticoid negative feedback on the HPA axis in five inbred rat strains," American Journal of Physiology, vol. 274, no. 2, pp. R420-R427, 1998. 


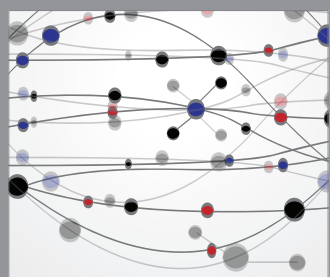

The Scientific World Journal
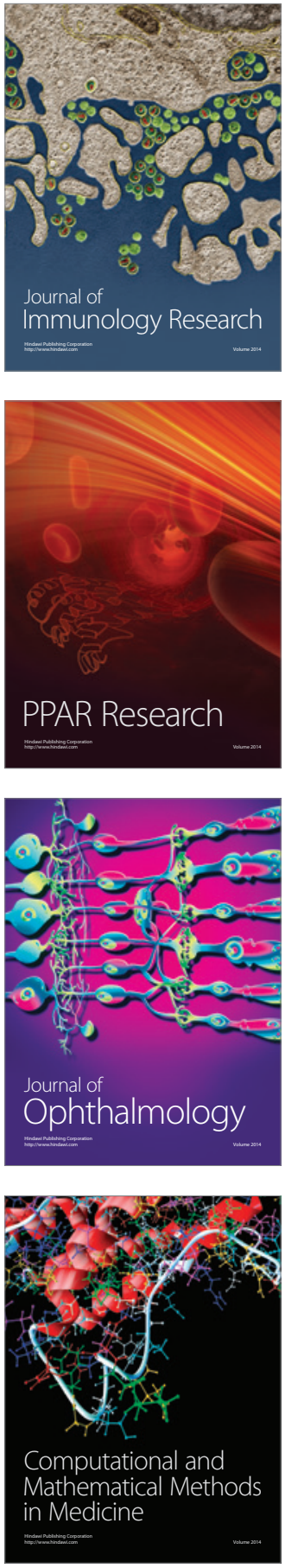

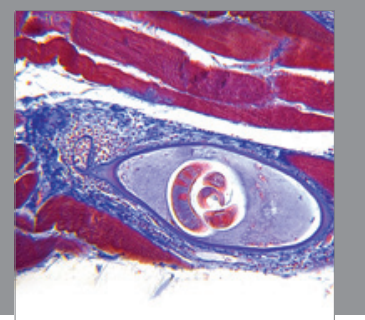

Gastroenterology

Research and Practice
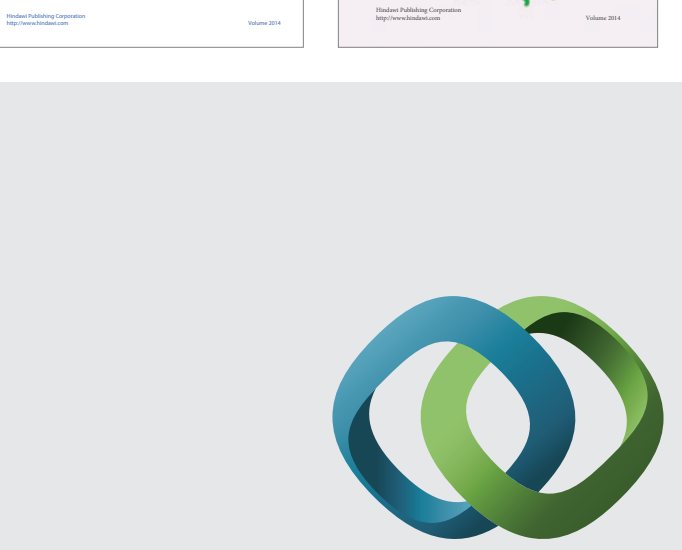

\section{Hindawi}

Submit your manuscripts at

http://www.hindawi.com
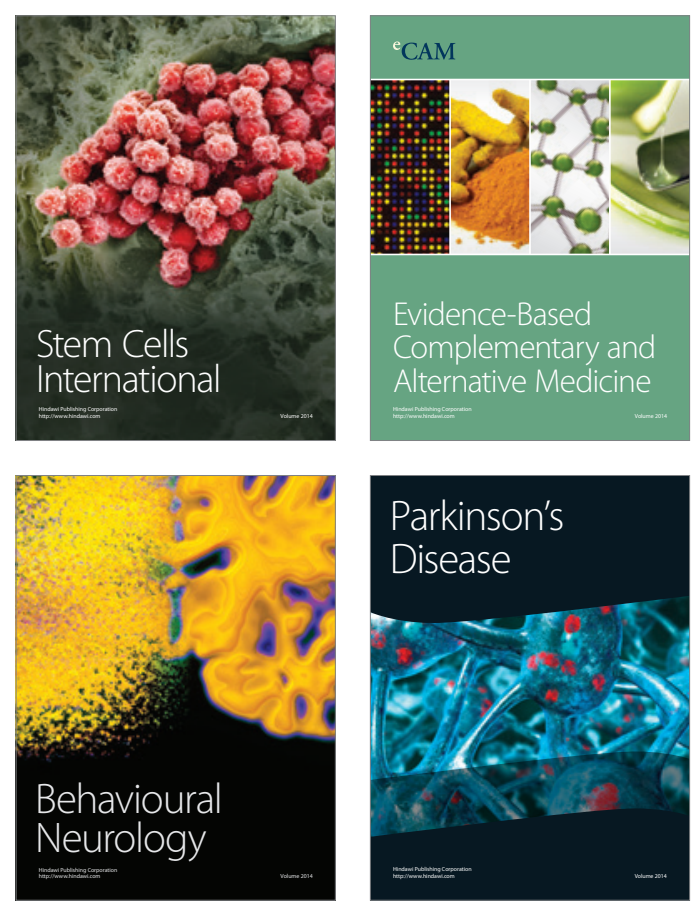

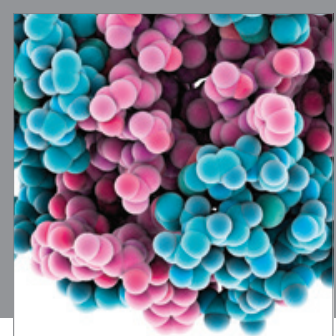

Journal of
Diabetes Research

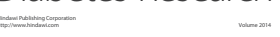

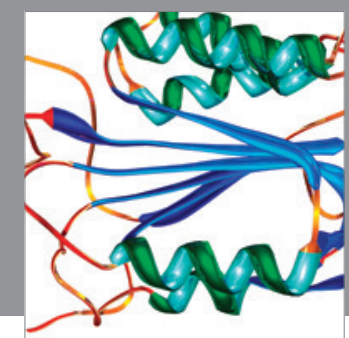

Disease Markers
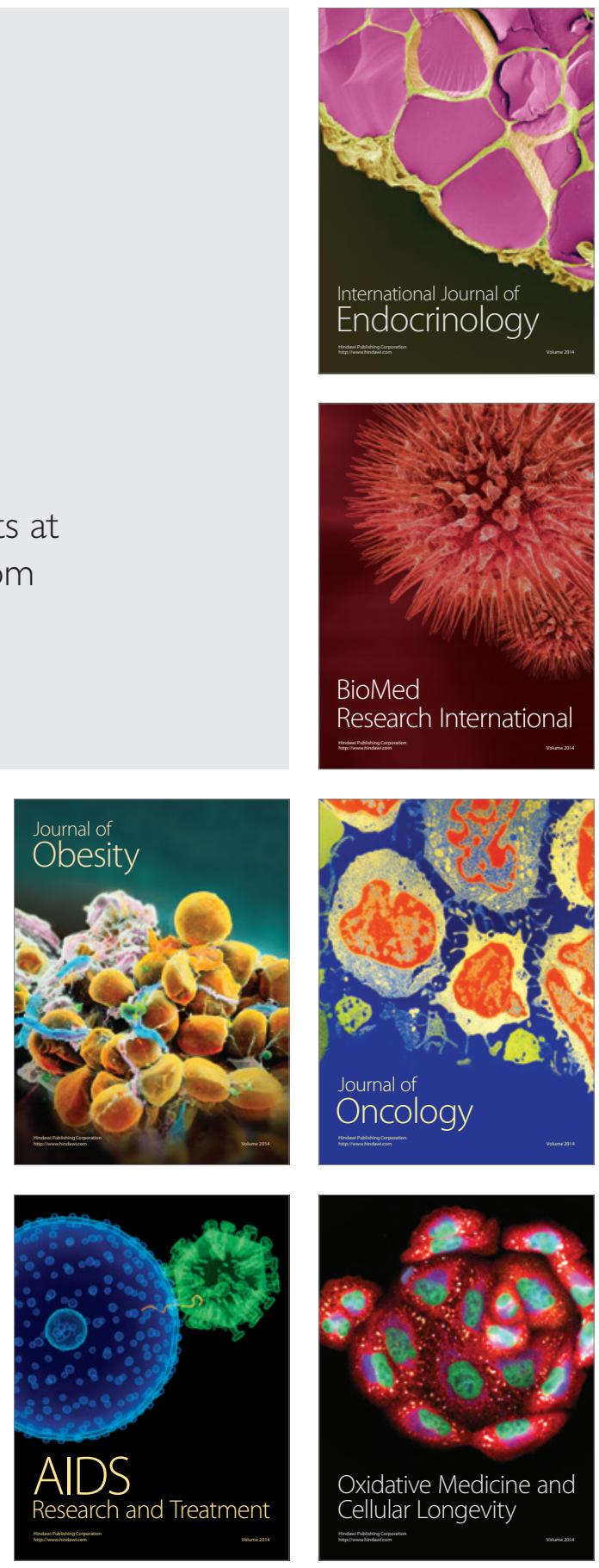